\title{
On the Structure and Function of the Alimentary Canal of Tigriopus japonicus (Copepoda; Harpacticoida)-I Histological Structure
}

\author{
Kazuma YoshikoshI* \\ (Received May 21, 1975)
}

\begin{abstract}
This study was carried out to elucidate the structure of the alimentary canal of Tigriopus japonicus with special attention directed to the cellular constitution of the mid-gut epithelium. The fore-gut is a rather elongated narrow chitinized tube. The gut has two sets of striated muscles: a circular set participating in constriction and another set participating in dilation. The whole of the mid-gut, wide and sac-like in the anterior region of the body and cylindrical in the posterior region, is lined by a single layer of epithelium devoid of chitinous covering. Two separate glandular epithelia were seen in the mid-gut, and the secretory mechanism of the glandular epithelial cells is discussed. Interspersed among the ordinary mid-gut epithelial cells, darkly stained, slender cells were always visible in every individual and the biological significance of the cells is considered to be a morphological picture of spontaneous senile decay of the mid-gut epithelial cells. The mid-gut has circular striated muscles arranged in bands and longitudinal "non-striated muscles. The hind-gut is a weakly chitinized short tube occupying the level of the last two abdominal segments in the female. The gut has densely arranged circular striated muscles and strong striated muscles participating in dilation.
\end{abstract}

It is well known that Copepoda constitutes one of the most important groups of the marine zooplankton having great diversity in form and mode of life. The biological significance and diversity of the animal aroused a great interest of those concerned, and numerous investigations have been carried out. However, comparatively little has been undertaken regarding internal morphology and physiology, and much work remains in these fields. This research series has been undertaken in order to elucidate the structure and function of the alimentary canal of copepods. The present paper deals with the histological structure of the alimentary canal of Tigriopus japonicus.

\section{Material and Methods}

Tigriopus japonicus is a neritic species in the warm waters of Japan and frequently encountered in large numbers in tide pools. Adults and some copepodid stage larvae which had been kept in a glass tank in this laboratory were used in addition to some adults obtained from the outdoor pond of the Nagasaki Prefectural Fisheries Experimental Station in the present study.

For fixation of tissue specimens, Helly's fluid, ZENKER's fluid, CHAMPY's fluid,

* Faculty of Fisheries, Nagasaki University, Nagasaki, Nagasaki, Japan.（吉越一馬：長崎大学水産学 部) 
CARNOY's fluid, and 10\% formalin neutralized with calcium carbonate were tested, and the former three were found to give satisfactory results. After embedding in paraffin, serial sections were made and stained with HeidenHaIN's azan. A few sections were also stained with MAYER's acid hemalum and eosin, HeIDENHAIN's iron hematoxylin, or with periodic acid-SCHIFF (PAS) and MAYER's acid hemalum.

\section{Results}

Fore-gut The fore-gut is a rather elongated narrow chitinized tube. It runs from the mouth, slightly curving with convexity towards the frontal end of the head, to a wide mid-gut, and the upper end of it markedly projects into the mid-gut lumen (Figs. 1-3). The gut epithelium forms four longitudinal ridges which are composed of an anterior, a posterior, and two lateral ridges. Both anterior and posterior ridges are equal in size but are larger than the lateral ones in the lower part of the gut; all four ridges are of equal size in the upper part.

The gut has two sets of striated muscles: a circular set which participates in constriction and another participating in dilation. Both sets are stronger in the lower than in the upper part of the gut. The circular muscles form a series of bands encircling the gut (Fig. 2). The muscles for dilation extend from the chitinous inner wall of the gut to various points of the body wall and to the endosternite which is situated just behind the gut (Fig. 2). Several pairs of muscles connected to the lower and upper part of the anterior ridge extend to the anterior ventral and anterior dorsal body wall. Several non-paired muscles connected to the lower and upper part of the lateral ridges extend to the anterior ventro-lateral and anterior dorso-lateral body wall. About ten paired muscles extend from the posterior ridge to the endosternite.

Labral gland The labral glands total eight in number, four on each side of the labrum. Each is a large unicellular gland having its own opening into the buccal cavity. The granular secretion of the gland was stained blue or bluish purple with HEIDENHAIN's azan (Fig. 2) and red with MAYER's acid hemalum and eosin; it showed weak affinity to HEIDENHAIN's iron hematoxylin, but was essentially PAS negative.

Mid-gut The whole of the mid-gut, which is wide and sac-like in the anterior region of the body and cylindrical in the posterior region, is lined by a single layer of epithelium devoid of chitinous covering (Fig. 1).

In front of the opening of the fore-gut into the mid-gut, the gut forms a hemispherical diverticulum which is lined by a glandular epithelium (Figs. 1-3). The epithelium consists of large glandular cells with round or oval nuclei in the basal position of the cells. Interspersed among the glandular cells, are slender cells occuring in smaller numbers, and smaller oval nuclei which tend to take a central position in the cells (Fig. 1). In the free surface of these two types of cells, the striated border was visible, although it was less 


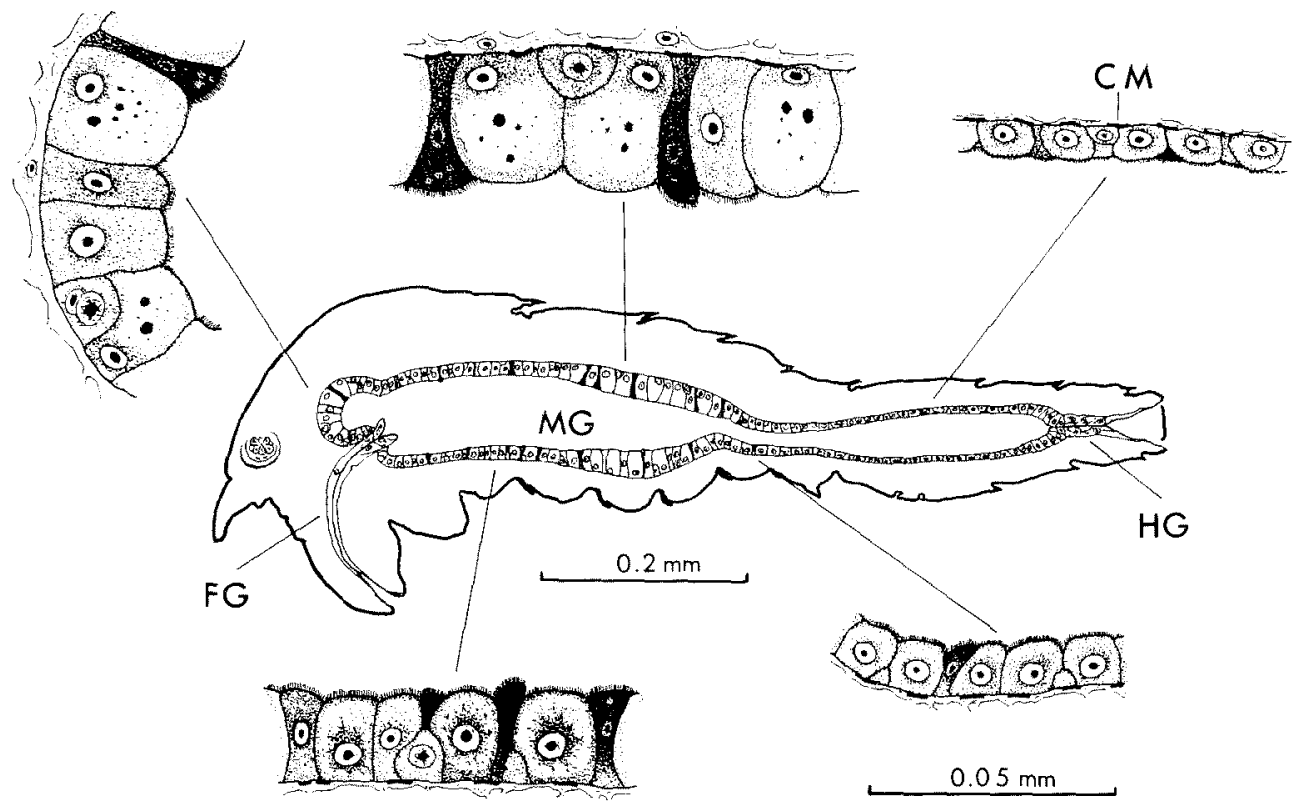

Fig. 1. Alimentary canal of Tigriopus japonicus, showing the cellular constitution of different parts of the mid-gut. Five enlarged figures are drawn to the scale in the lower part. $F G$ : fore-gut, $\mathrm{MG}$ : mid-gut, $\mathrm{HG}$ : hind-gut, $\mathrm{CM}$ : circular muscle.

clear in the fully matured glandular cells (Fig. 1). Furthermore, a few smaller cells with relatively large and distinct nuclei were always seen embedded in the basal portion of the epithelium. Smaller cells of this type were also visible in the mid-gut epithelium behind the diverticulum (Fig. 1).

Occasionally, some of the slender cells were intensely stained dark red with HEIDENHAIN's azan, dark blue with HeIdENHAIN's iron hematoxylin (Fig. 3), and dark red with MAYER's acid hemalum and eosin. These cells showed marked condensation in the nucleus and cytoplasm. This type of slender cell is herein arbitrarily referred to as "dark cells" on the basis of their peculiar staining properties. A small number of dark cells were also visible in all the copepodid stage larvae examined in the present study.

Behind the diverticulum there is a wide non-glandular epithelium extending to the anterior level of the 2 nd thoracic segment (Figs. 1 and 3). The epithelium consists of cubical cells with round, sometimes oval, nuclei in the central to basal positions of each cell and of slender cells with oval nuclei in the central position of each cell (Fig. 1). As a whole, the cubical cells tended to be hypertrophic in morphology (Figs. 3-5). In this region, the dark cells were always visible and their number varied in individual copepods. Several small vacuoles were observed in some dark cells.

Behind the non-glandular epithelium there is another glandular epithelium occupying 


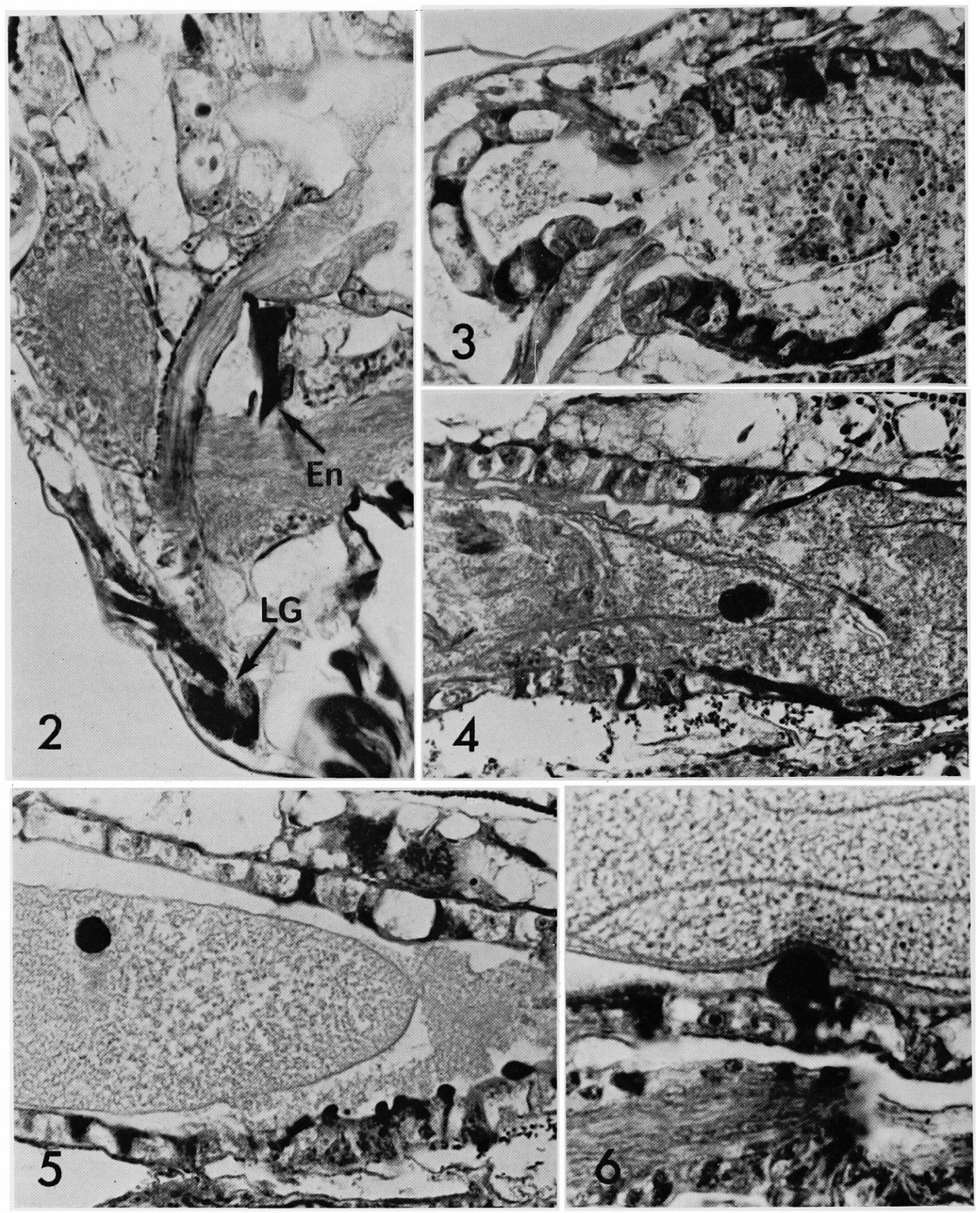

Fig. 2. Section through the cephalosome. LG : labral glands, En: endosternite.

Fig. 3. Mid-gut in the cephalosome. Notice darkly stained slender epithelial cells.

Figs. 4 and 5. Mid-gut in the metasome. Non-glandular epithelium in the left half and glandular one in the right half.

Fig. 6. Picture of shedding of a darkly stained mid-gut epithelial cell into the gut lumen. Figs. 2, 4-6. Zenker's fluid, Heidenhain's azan. Fig. 3. Helly's fluid, Heidenhain's iron hematoxylin. Figs. $2-5 . \times 475$, Fig. $6 . \times 1190$. 
the level of about the 2 nd and 3rd thoracic segments (Fig. 1). The cellular constitution of the epithelium is almost the same as that positioned in the anterior diverticulum. The epithelium displayed considerable variation in height in the process of secretion (Figs. 4 and 5). The fully matured glandular cells were found to become slender after the discharge of a secretory material. In some copepods, intermediate transitional forms between slender cells and mature glandular cells were observed. Moreover, dark cells were always visible in the epithelium (Figs. 4 and 5). Occasionally, a picutre of shedding of some dark cells into the gut lumen was observed (Fig. 6).

At the level of the 4th and 5th thoracic segments the gut narrows, constricted in some instances, and forms a transitional region between the gut in the anterior and posterior region of the body (Fig. 1). The epithelium consists of rather small cubical cells or irregular shaped cells.

The gut epithelium in the posterior region of the body consists of small and rather flat cells with oval nuclei in the basal position of the cells (Fig. 1). The striated border develops poorly in these cells compared with the epithelial cells in the anterior region of the body. The dark cells occurred less frequently. The posterior end of the gut is usually constricted and the epithelium thickens to some extent.

The mid-gut has circular striated muscles and longitudinal non-striated ones. The circular muscles form a series of bands encircling the gut and are more densely arranged in the posterior region of the body than in the anterior region (Fig. 1). No circular muscles are recognized in the anterior diverticulum.

Thin membranes which enclosed ingested food are always visible in the mid-gut lumen (Figs. 3-6).

The mid-gut is enveloped by a loose syncytial tissue, which is connected with the body wall and other tissues (Fig. 1).

Hind-gut The hind-gut is a weakly chitinized short tube occupying the level of the last two abdominal segments in the female (Fig. 1). The anterior half of the gut is usually constricted by densely arranged circular striated muscles. The gut also possesses strong striated muscles for dilation which extend to the dorsal, ventral, and lateral body walls. The anus opens at the posterior end of the last abdominal segment.

No appreciable differences in the structure of the alimentary canal were found between the female and the male.

\section{Discussion}

Large glandular cells in the mid-gut epithelium have been reported thus far in various species of copepods ${ }^{1-8)}$, have been considered to be digestive enzyme-secreting cells owing to the absence of additional glands opening into the gut. Since there are no glands opening into the gut in Tigriopus, it is probable that the digestive enzymes may be secreted by 
the glandular cells in the mid-gut epithelium. The presence of two separate glandular epithelia is considered unique. However, no differences were found in the histological pictures of both epithelia in the same animal.

CAPART $^{\text {() }}$ and EINSZPORN ${ }^{8)}$ reported, respectively, that the secretion of the glandular cells of parasitic Lernaeocera branchialis and Ergasilus sieboldi was holocrine. The glandular cells of Tigriopus showed, however, no diminution in apical cytoplasm or no discharge of the whole cell in the process of secretion. This suggests that the secretion of the glandular cells is merocrine. Furthermore, the fact that the fully matured glandular cells become slender after the discharge of a secretory material and the presence of intermediate transitional forms between slender cells and mature glandular cells suggest a cyclic restitution in each glandular cell similar to the mid-gut gland cells of the tropical freshwater crab, Atya spinipes. ${ }^{10)}$.

The dark cells found in the mid-gut epithelium were conspicuous in shape and staining properties. The present study revealed that the dark cells originated from the ordinary mid-gut epithelial cells and that they were always present in apparently healthy animals including some copepodid stage larvae. This suggests that the transformation from the ordinary mid-gut epithelial cells to the dark cells is a normal physiological phenomenon. Further, the tendency of condensation in the nucleus and cytoplasm of the dark cells and a picture of shedding of some dark cells into the gut lumen suggest some degenerative change, presumably an irreversible change, in the dark cells.

The above discussion indicates that the dark cells are very similar to the so-called dark cells in mammals which have been considered to be a morphological picture of spontaneous senile decay of parenchymal cells ${ }^{12,13)}$. TAUCHI et al. ${ }^{13)}$ assumed that the enhancement of function of the epithelial cells of the proximal convolution of the rabbit kidney was responsible for the senile decay of the cells. This is also conceivable in the case of Tigriopus from the fact that the dark cells are found in larger numbers in the mid-gut epithelium in the anterior region of the body which is a very active region whose functions of absorption and formation of chitinous membrane are important in addition to the secretion of digestive enzymes (in preparation). From the above discussion, it is also considered that the dark cells provided a morphological picture of spontaneous senile decay of the mid-gut epithelial cells which is of biological significance.

Lown ${ }^{3)}$ found narrow granular cells in the glandular epithelium of the mid-gut of Calanus finmarchicus. It is, however, not clear whether or not the narrow granular cells are in the same category as the dark cells in the absence of detailed description of the cells.

In the mid-gut of Tigriopus no embryonic zone was seen which is composed of embryonic cells or undifferentiated cells as found in the mid-gut gland of crabs ${ }^{10)}$ or crayfishes. ${ }^{9,11}$ However, smaller cells embedded in the mid-gut epithelium were always visible. The presence of a relatively large nucleus with dense chromatin of the smaller 
cells seems to suggest that the cells are younger than larger ones. Presumably, the loss of the epithelial cells by the shedding of the dark cells is balanced by the smaller cells or cells arising from the smaller cells.

\section{Acknowledgement}

I wish to express my sincere gratitude to Prof. Y. Kô, Faculty of Fisheries, Nagasaki University, for his guidance and continued encouragement, to Prof. T. HibrYa, Faculty of Agriculture, the University of Tokyo, for his interest and continued encouragement. I am indebted to Dr. S. FuJITA, the Nagasaki Prefectural Fisheries Experimental Station, for supplying Tigriopus specimens.

\section{References}

1) M. M. Hartog: Trans. Limn. Soc. Lond., Ser. 2, Zool., 5, 1-46 (1888).

2) W. J. Dakin: Int. Revue ges. Hydrobiol. Hydrogr., 1, 772-782 (1908).

3 ) E. Lowe: Trans. R. Soc. Edinb., 58, 561-603 (1935).

4) A. Steuer: Arb. zool. Inst. Univ. Wien, 15, 1-46 (1903).

5) W. Halisch: Z. Parasitenk., 11, 284-330 (1939).

6) A. CAPART: Cellule, 52, 159-212 (1948).

7) Y. Bouligant: Vie Milieu, 11, 335-380 (1960).

8) T. EINSZPORN: Acta parasit. pol., 13, 71-79 (1965).

9) W. JAcoBs: Z. Zellforsch. Mikroskop. Anat., 8, 1-62 (1928).

10) P. B. VAN WeEl: Physiol. Zool., 28, 40-54 (1955).

11) R. F. RoIzzI: Diss. Abstr., 27, 1329B (1966).

12) H. Tauchi and T. Nakamura: Nagoya Med. J., 1, 143-154 (1953).

13) H. TAuchi, T. Nakamura, and K. Yamada: Nagoya Med. J., 2, 169-176 (1954). 